\title{
Effects of hyperaccumulator plant straw on antioxidant enzyme activities and osmotic substances and malondialdehyde content of lettuce under cadmium stress
}

\author{
Guochao Sun ${ }^{1}$, Xiangting $\mathrm{Xu}^{2}$, Yunying Xiao ${ }^{2}$, Xiaohan $\mathrm{Wei}^{2}$, Yan Wang ${ }^{2}$ and Yi Tang ${ }^{*}$ \\ ${ }^{1}$ Institute of Pomology and Olericulture, Sichuan Agricultural University, Chengdu, Sichuan, 611130, China \\ ${ }^{2}$ College of Horticulture, Sichuan Agricultural University, Chengdu, Sichuan, 611130, China
}

\begin{abstract}
Lettuce (Lactuca sativa) is one of the most common green leafy vegetables, which is widely cultivated all over the world, but extremely sensitive to cadmium (Cd) contaminated in soil. The effects of three hyperaccumulator plants straw (Solanum nigrum, Bidens pilosa and Galinsoga parviflora) on the antioxidant enzyme activities and osmotic regulators and malondialdehyde (MDA) content under Cd stress were studied by pot culture. Compared with no straw, three kinds of hyperaccumulator straw of $S$. nigrum straw, B. pilosa straw and G. parviflora straw increased the content of soluble protein and proline in lettuce, the activity of peroxidase (POD) and catalase (CAT) in lettuce was also increased, and the content of MDA was decreased. The stress resistance of lettuce was improved and the toxicity of $\mathrm{Cd}$ to lettuce was alleviated by using three kinds of hyperaccumulator plant straw.
\end{abstract}

\section{Introduction}

Straw returning is considered to be one of the most promising eco-agricultural measures in China's cropland and has net mitigation potential, economic benefits, and air pollutant reduction [1]. However, plant straw may release some allelochemical to inhibit plant growth, such as reduce biomass and the content of photosynthetic pigments, while improving soil environment [2]. In farmland, heavy metals content may be increased by diffuse deposition, flowing water, application wastewater, pesticides, and fertilizer [3]. Cadmium (Cd) is a major agricultural problem in soil, and it is not essential element for crop growth but easily ingested and accumulated in plants, causing potential damage to plants [4]. There are many ways to alleviate Cd toxicity. Returning the hyperaccumulator plant straw to the field in this experiment is one of green environmental protection methods. Lettuce (Lactuca sativa) is one of the most common green leafy vegetables and widely planted all over the world. It is very sensitive to $\mathrm{Cd}$ and is easy to accumulate in edible parts. Moreover, its toxic symptoms are not obvious, which greatly increases the risk of Cd entering human body [5]. Solanum nigrum, Bidens pilosa and Galinsoga parviflora are common hyperaccumulator plants in farmland, which have the characteristics of convenient sampling, large number and wide distribution. This experiment explored the effects of hyperaccumulator plant straw on antioxidant enzyme activities and osmotic substances and MDA content of lettuce under Cd pollution; it provides a new idea for leaf vegetables to improve their resistance to heavy metals.

\section{Materials and Methods}

\subsection{Materials}

In June 2015, three kinds of Cd hyperaccumulator plants were collected from the surrounding farmland (not contaminated by heavy metals) in the Sichuan Agriculture University: S. nigrum, B. pilosa and $G$. parviflora, after removing the seeds, they are washed with distilled water. After 15 minutes of killing fresh at $105{ }^{\circ} \mathrm{C}$, they are dried to constant weight at $75{ }^{\circ} \mathrm{C}$. Cutting the dried straw into about $1 \mathrm{~cm}$ segments and set aside.

Lettuce is a common glass lettuce in Sichuan, and it has high purity, good quality, good tolerance and resistance, and can be planted all year round and sustainable harvest for more than 50 days.

The tested soil was paddy soil, which was taken from farmland not polluted by heavy metals around Chengdu campus of Sichuan Agricultural University. Its basic physical and chemical properties are as follows: $\mathrm{pH} 6.36$, organic matter $18.10 \mathrm{~g} / \mathrm{kg}$, total nitrogen $1.04 \mathrm{~g} / \mathrm{kg}$, total phosphorus $1.36 \mathrm{~g} / \mathrm{kg}$, total potassium $20.78 \mathrm{~g} / \mathrm{kg}$, hydrolyzable nitrogen $43.90 \mathrm{mg} / \mathrm{k}$, available phosphorus $92.71 \mathrm{mg} / \mathrm{kg}$, available potassium $134.25 \mathrm{mg} / \mathrm{kg}$, available $\mathrm{Cd}$ not detected. $\mathrm{CdCl}_{2} 2.5 \mathrm{H}_{2} \mathrm{O}$ analytical pure solution was added to the tested soil for heavy metal $\mathrm{Cd}$.

*Corresponding author's e-mail: 95459425@qq.com 


\subsection{Experimental design}

In June 2015, the air-dried and crushed soil was sifted through 300 meshes and loaded into barrels, each containing $20 \mathrm{~kg}$. The $\mathrm{Cd}$ concentration was $10 \mathrm{mg} / \mathrm{kg}$ by adding analytical pure $\mathrm{CdCl}_{2} 2.5 \mathrm{H}_{2} \mathrm{O}$ solution [7], after 30 days of moist storage, all contaminated soils are fully blended and packed in a pot of $3 \mathrm{~kg}$ per pot.

Full lettuce seeds were select for disinfection, evenly spread them on wet gauze, put them into $20{ }^{\circ} \mathrm{C}$ light incubator for germination, and then sow them in a pot dish with nutritive soil to raise seedlings. After one week of lettuce seedling raising, and three kinds of hyperaccumulator plant straw were applied to the prepared $\mathrm{Cd}$ contaminated soil, $6 \mathrm{~g}$ per pot, and mixed evenly, with no straw as the control. The experiment was divided into four treatments: no straw, $S$. nigrum straw, $B$. pilosa straw and G. parviflora straw. After a week of balancing and watering, selected healthy lettuce seedlings and transplant them into Cd-contaminated soil prepared with straw. Four plants were transplanted in each pot and nine pots were treated in each pot. After transplanting, the seedlings were placed in plastic greenhouse, and the soil moisture was maintained at about $80 \%$. After the lettuce grew $50 \mathrm{~d}$, antioxidant enzyme activities and osmotic substances and MDA content of lettuce were determined.

\subsection{Index determination}

Superoxide dismutase (SOD) activity was determined by NBT method; the activity of peroxidase (POD) was determined by guaiacol method; catalase (CAT) activity was determined by ultraviolet absorption method [7]. According to Bradford's method, the soluble protein content was determined by Coomassie brilliant blue method. The content of proline was determined by sulfosalicylic acid method, the content of soluble sugar was determined by anthrone colorimetry, determination of MDA by thiobarbituric acid [7].

\subsection{Statistical analyses}

All data are collated with Excel 2010 software; SPSS 20.0 was used for variance analysis and Duncan's new complex range method was used for multiple comparisons.

\section{Result}

\subsection{Effects of soil application of hyperaccumulator plant straw on antioxidant enzyme activities in lettuce leaf}

The activities of antioxidant enzymes in lettuce leaves increased after the application of hyperaccumulator plant straw (Table 1). The activity of SOD in lettuce leaves treated with $B$. pilosa straw increased significantly by $20.04 \%$ compared with the control $(\mathrm{P}<0.05)$. As far as POD activity of lettuce leaves was concerned, the application of S. nigrum straw, B. pilosa straw and $G$. parviflora straw increased $63.13 \%(\mathrm{P}<0.05), 20.00 \%$ ( $\mathrm{P}$ $<0.05)$ and $13.06 \%(\mathrm{P}<0.05)$ respectively compared with the control. The CAT activity of lettuce leaves from high to low was as follows: B. pilosa straw $>G$. parviflora straw $>S$. nigrum straw $>$ no straw. The CAT activity of lettuce leaves was significantly increased by applying B. pilosa straw, which was $20.88 \%$ higher than that of the control $(\mathrm{P}<0.05)$.

Table 1. Effects of hyperaccumulate plant straw on antioxidant enzyme activity of lettuce

\begin{tabular}{lccc}
\hline Plant straw & $\begin{array}{c}\text { SOD activity } \\
(\mathrm{U} / \mathrm{g})\end{array}$ & $\begin{array}{c}\text { POD activity } \\
(\mathrm{U} / \mathrm{g})\end{array}$ & $\begin{array}{c}\text { CAT activity } \\
(\mathrm{U} / \mathrm{g})\end{array}$ \\
\hline No straw & $104.37 \pm 4.99 \mathrm{c}$ & $370.36 \pm 25.45 \mathrm{~d}$ & $24.62 \pm 2.08 \mathrm{~d}$ \\
S. nigrum straw & $100.08 \pm 10.33 \mathrm{~d}$ & $604.18 \pm 28.28 \mathrm{a}$ & $27.96 \pm 1.27 \mathrm{c}$ \\
B. pilosa straw & $125.29 \pm 5.35 \mathrm{a}$ & $444.45 \pm 28.28 \mathrm{~b}$ & $29.76 \pm 2.12 \mathrm{a}$ \\
G. parviflora straw & $105.63 \pm 3.21 \mathrm{~b}$ & $418.72 \pm 31.11 \mathrm{c}$ & $28.53 \pm 1.27 \mathrm{~b}$ \\
\hline
\end{tabular}

Different lowercase letters in the same column indicate significant difference $(\mathrm{P}<0.05)$.

\subsection{Effects of soil application of hyperaccumulator plant straw on osmotic substances and malondialdehyde (MDA) content in lettuce}

Application of hyperaccumulator plant straw reduced the MDA content of lettuce leaves, and increased the soluble protein and proline content of lettuce (Table 2). As far as MDA content was concerned, the treatments with $S$. nigrum straw, B. pilosa straw and $G$. parviflora straw were significantly lower than those of the control, which decreased by $2.12 \%(\mathrm{P}<0.05), 30.02 \%(\mathrm{P}<0.05)$ and
$15.06 \%(\mathrm{P}<0.05)$, respectively. The application of hyperaccumulator plant straw increased the soluble protein content of lettuce, the soluble protein content of lettuce with $B$. pilosa straw was the highest, $47.63 \%$ higher than that of the control $(\mathrm{P}<0.05)$, followed by the treatment with $G$. parviflora straw, $29.64 \%$ higher than that of the control $(\mathrm{P}<0.05)$. The order of soluble sugar content in lettuce from high to low was: $S$. nigrum straw $>$ no straw $>$ B. pilosa straw $>$. parviflora straw. As far as proline content was concerned, the treatment with G. parviflora straw had the highest proline content, which increased by $186.59 \%$ compared with the control $(\mathrm{P}<0.05)$, followed by B. pilosa straw and S. nigrum straw. 
Table 2. Effects of hyperaccumulate plant straw on the Contents of osmotic substances and MDA of lettuce

\begin{tabular}{ccccc}
\hline Plant straw & $\begin{array}{c}\text { MDA content } \\
(\mathrm{nmol} / \mathrm{g})\end{array}$ & $\begin{array}{c}\text { Soluble protein content } \\
(\mu \mathrm{g} / \mathrm{g})\end{array}$ & $\begin{array}{c}\text { Soluble sugar content } \\
(\%)\end{array}$ & $\begin{array}{c}\text { Proline content } \\
(\mu \mathrm{g} / \mathrm{g})\end{array}$ \\
\hline No straw & $10.36 \pm 0.63 \mathrm{a}$ & $88.66 \pm 6.68 \mathrm{~d}$ & $0.47 \pm 0.01 \mathrm{~b}$ & $11.63 \pm 0.41 \mathrm{~d}$ \\
S. nigrum straw & $10.14 \pm 0.12 \mathrm{~b}$ & $102.91 \pm 7.87 \mathrm{bc}$ & $0.59 \pm 0.01 \mathrm{a}$ & $19.15 \pm 0.41 \mathrm{c}$ \\
B. pilosa straw & $7.25 \pm 0.65 \mathrm{~d}$ & $130.89 \pm 12.34 \mathrm{a}$ & $0.45 \pm 0.01 \mathrm{~b}$ & $28.41 \pm 1.23 \mathrm{~b}$ \\
G. parviflora straw & $8.80 \pm 0.24 \mathrm{c}$ & $114.94 \pm 10.80 \mathrm{~b}$ & $0.38 \pm 0.03 \mathrm{c}$ & $33.33 \pm 0.82 \mathrm{a}$ \\
\hline
\end{tabular}

Different lowercase letters in the same column indicate significant difference $(\mathrm{P}<0.05)$.

\section{Conclusion}

Under Cd stress, the toxicity of $\mathrm{Cd}$ to lettuce was alleviated by applying hyperaccumulator plants straw $(S$. nigrum, B. pilosa and G. parviflora) in soil. The activity of antioxidant enzymes and the content of osmotic regulators were increased, and the content of MDA was decreased. Under the condition of $\mathrm{Cd}$ pollution, the application of three kinds of hyperaccumulate plant straw can alleviate the toxicity of heavy metals to vegetables, and the reduction of $\mathrm{Cd}$ content in soil by application hyperaccumulator plants and the safe production of vegetables need to be further studied.

\section{References}

1. Lu, F., Wang, X., Han, B., Ouyang, Z., Zheng, H. (2010) Modeling the greenhouse gas budget of straw returning in China. Annals of the New York Academy of Sciences, 1195: 107-130.

2. Peng, L., Chen, F., Huang, J., Wen, Q., Liao, M., Lin, L., Jiang, W., Li, H. (2018) Effects of different straw mulching treatments on cadmium accumulation in Chrysanthemum sulfate. Journal of Sichuan Agricultural University, 30 (3):303-308

3. Conversa, G., Miedico, O., Chiaravalle, A. E., Elia, A. (2019) Heavy metal contents in green spears of asparagus (Asparagus officinalis L.) grown in Southern Italy: Variability among farms, genotypes and effect of soil mycorrhizal inoculation. Scientia Horticulturae, 256:108559.

4. Sun, J., Zhou, X., Wu, X., Lu, B., Dai, Ch., Shen, J. (2019) Research and analysis of cadmium residue in tomato leaves based on WT-LSSVR and Vis-NIR hyperspectral imaging. Spectrochimica Acta Part A: Molecular and Biomolecular Spectroscopy, 212:215-221.

5. Wei, S., Zhou, Q., Wang, X. Zhang, K., Guo, G., Ma Lena Q. (2005) A newly-discovered Cd-hyperaccumulator Solanum nigrum L. Chinese Science Bulletin, 50 (1):33-38.

6. Lin, L., Liu, Q., Shi, J., Sun, J., Liao, M., Mei, L. (2014) Intercropping different varieties of radish can increase cadmium accumulation in radish. Environmental Toxicology and Chemistry, 33 (9): 1950-1955.
7. Zhang, Y. (2009) Plant Physiology Experiment Course. Higher Education Press, Beijing. 